\title{
Oxidative DNA Damage in Blood of CVD Patients Taking Detralex
}

\author{
Krzyściak Wirginia $^{\mathrm{a}, \mathrm{b}, *}$, Cierniak Agnieszka $^{\mathrm{c}}$, Kózka Mariusz ${ }^{\mathrm{d}}$ and Kozieł Joanna ${ }^{\mathrm{e}}$ \\ ${ }^{a}$ Department of Medical Diagnostics, Jagiellonian University, Medical College, Pharmacy Faculty, Krakow, Poland \\ ${ }^{b}$ Department of Radioligand, Chair of Pharmacobiology, Jagiellonian University, Medical College, Pharmacy Faculty, \\ Krakow, Poland \\ ${ }^{c}$ Department of General Biochemistry; Faculty of Biochemistry, Biophysics and Biotechnology, Jagiellonian University, \\ 7 Gronostajowa Str., 30-387 Krakow, Poland \\ ${ }^{d}$ Department of General Surgery, Jagiellonian University Medical College, 21 Kopernika Str., 31-501 Krakow, Poland \\ ${ }^{e}$ Department of Microbiology, Faculty of Biochemistry, Biophysics and Biotechnology, Jagiellonian University, 7 \\ Gronostajowa Str., 30-387 Krakow, Poland
}

\begin{abstract}
The main goal of the work reported here was to determine the degree of oxidative/alkali-labile DNA damages in peripheral blood as well as in the blood stasis from varicose vein of (chronic venous disorder) CVD patients. Moreover, determination of the impact of Detralex usage on the level of (oxidative) DNA damages in CVD patients was evaluated as well.

The degree of oxidative DNA damages was studied in a group consisted of thirty patients with diagnosed chronic venous insufficiency (CVI) in the 2nd and 3rd degree, according to clinical state, etiology, anatomy and pathophysiology (CEAP), and qualified to surgical procedure. The control group consisted of normal volunteers (blood donors) qualified during standard examinations at Regional Centers of Blood Donation and Blood Therapy.

The comet assay was used for determination of DNA damages.

Analyses of the obtained results showed increase in the level of oxidative/alkali-labile DNA damages in lymphocytes originating from antebrachial blood of CVD patients as compared to the control group (Control) $(p<0.002$; ANOVA). In addition, it was demonstrated that the usage of Detralex ${ }^{\circledR}$ resulted in decrease of the level of oxidative/alkali-labile DNA damages in CVD patients as compared to patients without Detralex ${ }^{\circledR}$ treatment $(p<0.001$; ANOVA).

Based on findings from the study, it may be hypothesized about occurrence of significant oxidative DNA damages as the consequence of strong oxidative stress in CVD. In addition, antioxidative effectiveness of Detralexu ${ }^{\circledR}$ was observed at the recommended dose, one tablet twice daily.
\end{abstract}

Keywords: Reactive oxygen species (ROS), chronic venous insufficiency (CVI), micronized purified flavonoid fraction (MPFF).

\section{INTRODUCTION}

Chronic venous diseases (CVDs) represent one of the oldest known chronic human illnesses. Earliest data describing varicose veins, one of the main syndromes of chronic venous insufficiency (CVI) and its treatment are dated to antiquity [1].

Within theories trying to explain the development of chronic venous inefficiency, the key role is played by the "leukocyte trap". In this phenomenon, highly significant role is played by reactive oxygen species (ROS) and reactive nitrogen species (RNS). Superoxide anion $\left(\mathrm{O}_{2}^{-}\right)$, hydroxyl radical $\left(\mathrm{OH}^{\circ}\right)$, hydroperoxide radical $\left(\mathrm{HO}_{2}{ }^{\circ}\right)$, hydroxy peroxide

*Address correspondence to this author at the Department of Medical Diagnostics, Pharmacy Faculty, UJCM, 9 Medyczna Str. 30-688 Krakow, Poland; Tel: +4812 6205760; Fax: +4812 6205400;

E-mail: wirginiakrzysciak@cm-uj.krakow.pl
$\left(\mathrm{H}_{2} \mathrm{O}_{2}\right)$, oxygen singlet $\left(\mathrm{O}_{2}{ }^{\circ}\right)$ take part in damaging peritissue structures [2]. Oxidative damage of deoxyribonucleic acid occurs because of hydroxyl radical $\left(\mathrm{OH}^{-}\right)$action. This phenomenon is explained by two concepts. The first concept says about reaction of genetic material with $\mathrm{OH}^{*}$, which was generated in Fenton reaction with participation of $\mathrm{Cu}^{1+}$ or $\mathrm{Fe}^{2+}$ ions. The second concept indicates on elevated intracellular level of free $\mathrm{Ca}^{2+}$ ions, which results in activation of $\mathrm{Ca}^{2+}$-depandant nucleases responsible for DNA degradation $[3,4]$. Initiated oxidative DNA damages cause instability of genetic material because of mutation and it finally can result in cell death.

Human organisms try to be protected from oxidative changes in different ways. On the level of DNA, the protection is based on two mechanisms of elimination of free radical-induced DNA damages. The first of them, base-excision repair (BER) removes modified nucleotide bases by hydroly- 
sis of $\mathrm{N}$-glycosidic bond through mono- and bifunctional glycosylases. Monofunctional glycosylases break the bond between impaired nucleoside base and deoxyribose moiety causing generation of non-purine and non-pyrimidine sites. Besides the removal of modified base and generation of nonpurine and non-pyrimidine sites, bifunctional glycosylases have lyase properties, which enable removal of abovementioned sites through $\beta$-termination. After this mechanism, a singe nucleotide gap is left in DNA structure. On the other side, NER mechanism is not as specific as BER mechanism and requires a lot of energy by ATP hydrolysis. Following modifications in DNA conformation are removed through NER mechanism: photodimers, pyrimidins, adducts with different substitute, such as 1, N2-propano 2'deoxyguanosine adduct. The NER mechanism relies on cleaving of improper fragment containing damage by nuclease and elimination of this fragment [5].

Difference between these two repairing mechanisms relies on the fact that BER repairs DNA damages, which does not affect the DNA helical structure, whereas NER is an active mechanism towards damages, which change DNA conformation.

In pharmacotherapy of CVI, drugs of natural origin are applied. Detralex $(450 \mathrm{mg}$ of diosmin and $50 \mathrm{mg}$ of hesperidin) plays a key role here. In other countries, this drug is marketed under a name Daflon 500. The effectiveness of the drug has been studied and confirmed in numerous clinical trials, including RELIFE trial that covered 23 countries [6].

\section{THE AIM OF THE WORK}

The aim of the work was verification of research hypothesis if the level of DNA damages (alkali-labile/oxidative damages) in peripheral blood lymphocytes (PBL) of patients with chronic venous disease is higher than in a control group (normal population).

Besides, we were trying to answer the question if therapy with phlebotropic drug (Detralex) of CVI patients is correlated in any way with decrease in the level of these damages.

\section{MATERIALS \& METHODS}

Degree of oxidative DNA damages was studied in a group that consisted of ten patients with diagnosed with chronic venous insufficiency, in the 2 nd and 3rd degree, according to clinical state, etiology, anatomy and pathophysiology (CEAP). These patients were qualified for surgical procedure from February to May 2010 at the II Department of General Surgery in Cracow. Patient's qualification for the study was carried out by phlebologist during ultrasonography (USG) examination of venous vessels of lower limbs (DOPPLER).

The Bioethical Committee of the Jagiellonian University in Cracow (KBET/162/B/2009) expressed positive approval about the study.

The control group consisted of 30 normal volunteers (blood donors) qualified during standard examinations at Regional Centers of Blood Donation and Blood Therapy. The Comet assay, electrophoresis of individual cells on agarose gels were employed for the determination of DNA damages [7]. The cell viability assay with fluorescein diacetate (FDA) and ethidium bromide (EtBr) were used to evaluate the viability of cells before every study [8]. Cell viability was above $95 \%$.

\section{Isolation of Lymphocytes from Peripheral and Stasis Blood}

Venous blood was collected from sick and normal donors to polypropylene tubes containing $\mathrm{K}_{2}$ EDTA $(1.5 \mathrm{mg} / 1 \mathrm{ml})$, stratified mildly along the wall of the Histopaqu-1077 tube (1:1 ratio) creating a density gradient. Then, it was centrifuged at room temperature for 40 minutes, $400 \times \mathrm{g}$. After mild centrifugation, application of circular movement, the lymphocyte layer (Fig. 1) was transferred to polypropylene tubes (Falcon). Cold PBS free of $\mathrm{Ca}^{2+}$ and $\mathrm{Mg}^{2+}$ ions was added to collected lymphocytes and the whole mixture was centrifuged at $4^{\circ} \mathrm{C}$ for $10 \mathrm{~min}$ at $700 \times \mathrm{g}$. This step was repeated twice. The cells were counted with the use of Bürker chamber and suspended later in $2 \times 10^{6}$ cells $/ \mathrm{ml}$ concentration of PBS. Such prepared cell suspension was frozen at $-80^{\circ} \mathrm{C}$ in a box filled out with isopropanol in a medium containing $90 \% \mathrm{FBS}+10 \%$ DMSO.

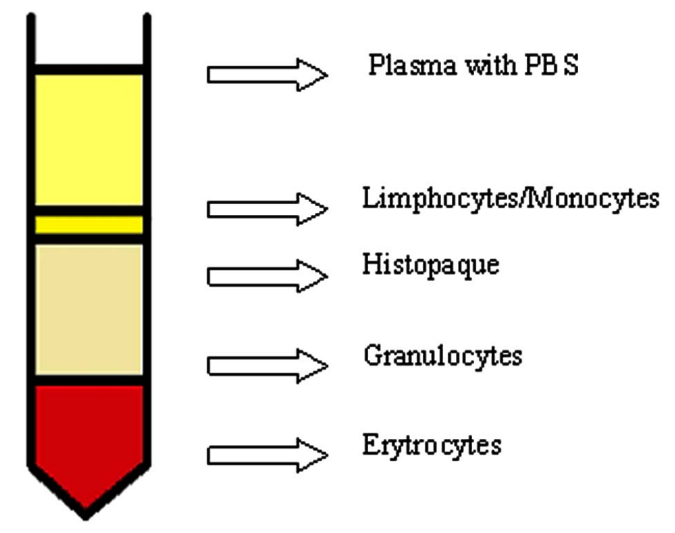

Fig. (1). Density gradient centrifugation.

\section{Cells Viability}

For the determination of the number of live cells, $25 \mu$ of working solution [25 $\mu \mathrm{l} \mathrm{FDA} \mathrm{in} \mathrm{acetone}(5 \mathrm{mg} / \mathrm{ml}), 350 \mu \mathrm{l}$ $\mathrm{EtBr}(10 \times$ diluted in PBS $)$ and $4.8 \mathrm{ml} \mathrm{PBS}]$ was added to the total volume of $20 \mu \mathrm{l}$ (1 drop) of cell suspension. Five minutes later, the number of live cells was estimated on slides under fluorescence microscope with the use of a blue filter. The total number of cells, as well as the total number of live cells was determined as the percentage of live cells. The live cells were dyed with fluorescein on green color and the nuclei of dead cells were dyed with ethidium bromide on orange color (Figs. $\mathbf{2}$ and 3). At least 200 cells were counted on each section.
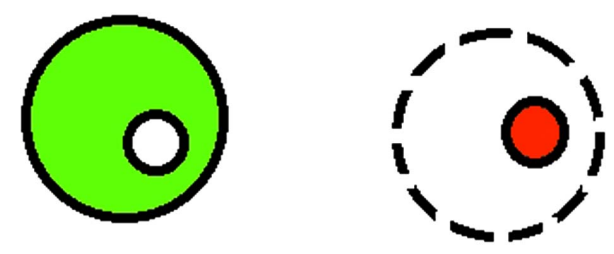

Fig. (2). Determination of cell viability. 


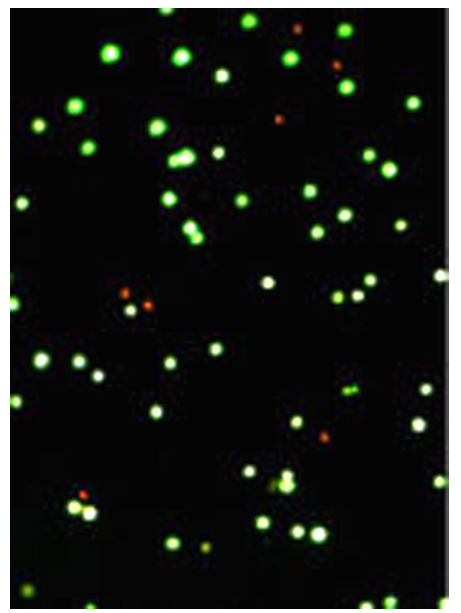

Fig. (3). Working model of FDA test: fluorescein is aggregated in cells with intact cell membrane; a fluorescein is leaking out from cells with discontinue membrane, ethidium bromide is binding to nucleic acids. Image from fluorescence microscopy (10x magnitude): nuclei of dead cells (red color) stained with ethidium bromide.

\section{Alkaline Electrophoresis of Individual Cells in Agarose Gel by Comet Method}

Oxidative DNA damages are studied by electrophoresis of single cell in agarose gel [7]. Determination of the oxidative damages is based on the detection of 8-oxoguanine with the use of formamidopyrimidine DNA glycosylase (Fpg) [9].

During the first stage of the study, sections were prepared. For this purpose, previously isolated and frozen (at $80^{\circ} \mathrm{C}$ ) lymphocytes were defrosted in a water bath at $36^{\circ} \mathrm{C}$, which allowed to keep high cell viability (above $95 \%$ ). Then, the cells were suspended in cold PBS $\left(4^{\circ} \mathrm{C}\right)$ and total concentration of $1.5 \times 10^{6}$ cells $/ \mathrm{ml}$ was obtained. Such prepared samples were centrifuged at $230 \times \mathrm{g}$ for $8 \mathrm{~min}$ at $4^{\circ} \mathrm{C}$ (a centrifuge with horizontal rotor). Washing with PBS was repeated thrice, keeping the same conditions as mentioned above.

The cell suspension ( 30,000 cells) at volume of $85 \mu 1$ was re-suspended in $225 \mu \mathrm{l}(0.5 \%)$ of low melting point agarose (LMPA) and left in a water bath $\left(37^{\circ} \mathrm{C}\right)$. Then, the volume of $100 \mu \mathrm{l}$ of cells in agarose were smeared on slides, which were earlier coated with thin layer $(100 \mu \mathrm{l})$ of $0.5 \%$ normal melting point agarose (NMPA) and left to dry out. The slides were covered with cover slips and placed on the ice. After 10 $\mathrm{min}$, the cover slips were removed, and slides were placed in the lysis buffer $(2.5 \mathrm{M} \mathrm{NaCl}, 100 \mathrm{mM}$ EDTA, $10 \mathrm{mM}$ Tris, $\mathrm{pH} 10$, with addition of $1 \%$ Triton $\mathrm{X}-100$ and $10 \%$ DMSO) for $1 \mathrm{~h}$ at $4^{\circ} \mathrm{C}$ in dark to eliminate extra DNA damages.

After lysis, sections were placed in re-distillated water and washed twice with cold HEPES buffer (40 mM HEPES; $0.1 \mathrm{M} \mathrm{KCl} ; 0.5 \mathrm{mM}$ EDTA; $0.2 \mathrm{mg} / \mathrm{ml} \mathrm{BSA}, \mathrm{pH} 8.0$ with $\mathrm{KOH} ; 10 \times$ concentrated stored at $-20^{\circ} \mathrm{C}$ ). An optimal environment for enzyme action (formamidopyrimidine DNA glycosylase) was reached. On each section was dropped 50 $\mu 1$ of Fpg, $0.1 \mathrm{U} / \mathrm{ml}$. Slides with only HEPES buffer were used as the control.

Such prepared sections were covered with cover slips and placed in humid chamber at $37^{\circ} \mathrm{C}$ for $30 \mathrm{~min}$. After incubation, the slides were placed in the apparatus for horizontal electrophoresis and left for $40 \mathrm{~min}$ in a buffer for electrophoresis $(1 \mathrm{mM}$ EDTA, $300 \mathrm{mM} \mathrm{NaOH} \mathrm{pH}>13)$ at $4^{\circ} \mathrm{C}$ to loosen nuclear super-coiled DNA. The sections were subjected to low-voltage electrophoresis at $300 \mathrm{~mA}, 0.74 \mathrm{~V} / \mathrm{cm}$ for $30 \mathrm{~min}$ at $4^{\circ} \mathrm{C}[10]$. All the stages of the experiment were carried out in dark to eliminate any extra DNA damages. After gel electrophoresis, the slides were washed three times with neutral cold buffer $\left(0.4 \mathrm{M}\right.$ Tris, $\left.\mathrm{pH} 7.5,4^{\circ} \mathrm{C}\right)$, and placed in cold $100 \%$ methanol for 5 min to fix the sections and then left to dry out. Sections prepared in this way can be stored for a long time (months and even years). Prior to analysis under fluorescent microscope, the sections were submerged for $5 \mathrm{~min}$ in re-distilled water and stained with propidium iodide at concentration of $2.5 \mu \mathrm{g} / \mathrm{ml}$. For visualization of DNA damages, the epifluerescence microscope (Olympus IX-50) equipped with the source of fluorescence was used. The analysis of oxidative DNA damages was carried out with the COMET PLUS 2.9 software (Comet Plus, Theta System Gmbh, Germany). The most frequently used parameter for the determination of DNA damages was the percentage content of DNA in the comet's tail. These data were collected for 70 random images of comets obtained from slide. The analysis were done in two replicates (Fig. 4).

\section{RESULTS}

Hypothesis about the effect of CVI on alkali-labile DNA damages of lymphocytes from human blood was confirmed.

The CVI patients demonstrated significantly higher level of alkali-labile DNA damages in PBLs as compared to the control group (normal patients) $(p<0.001$, U Mann-Whitney test) (Fig. 5).

Similar results were obtained at the level of oxidative DNA damages. The CVI patients demonstrated significantly higher level of oxidative DNA damages as compared to the control group ( $p<0.001$, U Mann-Whitney test) (Figs. 6 and 7).

Patients applying Detralex (one tablet twice a day) demonstrated significantly lower level of alkali-labile/oxidative DNA damages than patients who did not take the drug ( $p<$ 0.001; ANOVA rang Kruskala-Wallis) (Figs. 8 and 9). The level of alkali-labile DNA damages in PBLs from normal donors was significantly lower than the alkali-labile DNA damages in PBLs from CVI patients (Fig. 8) as well as in relation to alkali-labile DNA damages of blood stasis lymphocytes (BSL) originating from varicose vein CVI patients $(p<0,0001$; ANOVA rang Kruskala-Wallis)

\section{DISCUSSION}

\section{Effect of CVI on DNA Damages in Human Blood Lymphocytes}

Hypothesis about the effect of CVI on alkali-labile DNA damages in human blood lymphocytes was confirmed. Besides a number of biochemical changes, chronic venous insufficiency also increased the number of oxidative damages in purine bases, mainly 8-oxoguanine, 2, 6-diamino4hydroxyl-5-formamidopirymidine, 4, 6-diamino-5 - formamidopirimidine recognized by formamidopirimidine glycolicase. 

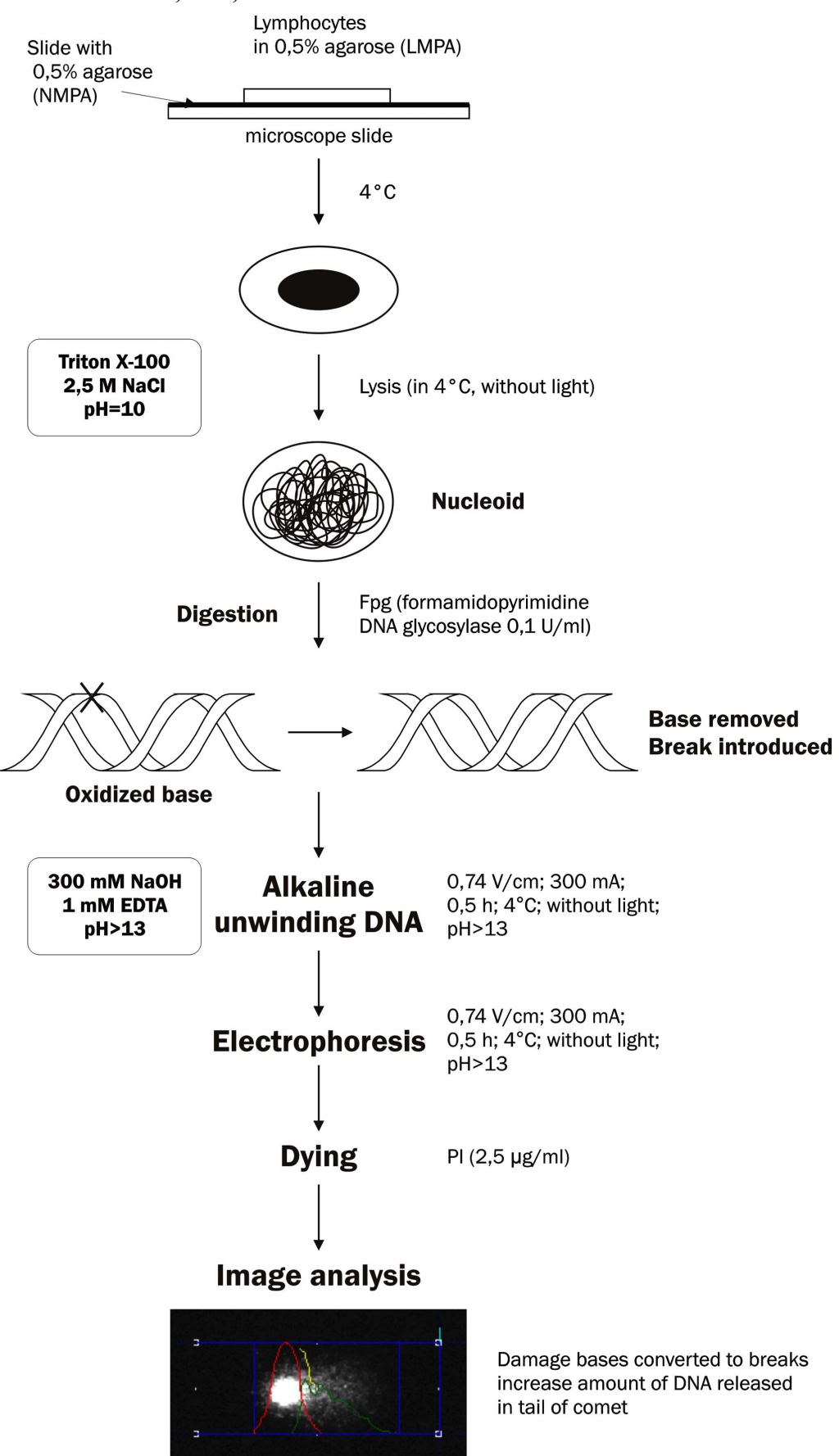

Damage bases converted to breaks increase amount of DNA released in tail of comet

Fig. (4). Schematic representation of the comet assay incorporating lesion-specific formamidopyrimidine DNA glycosylase (Fpg).

Differences between DNA damages in PBLs from normal patients (donors of blood for Regional Centers of Blood Donation and Blood Therapy) in comparison to CVI patients were statistically significant. Similar situation concerned stasis blood from varicose vein, where increase in DNA damages in CVI patients was observed. Differences between DNA damages in PBLs from normal patients and BSLs from CVI patients were statistically significant. Moreover, DNA damages in BSLs from varicose veins were higher than in PBLs from the same CVI patients. These differences were statistically significant as well.

Obtained results seem to be unique; because no paper was found in an electronic database presenting observed by us effect of CVI on DNA damages.
Cooke M. et al. demonstrated that cleavage of supercoiled, double-stranded DNA occurred during carcinogenesis, inflammation, and cardiac diseases. Formation of $\mathrm{O}_{2}^{-}$ and $\mathrm{H}_{2} \mathrm{O}_{2}$ by xanthine oxidase (XO) increased during reperfusion after hypoxia in cardiac disease. Development of CVI involves many different stages. Organic peroxides and $\mathrm{H}_{2} \mathrm{O}_{2}$ are promoters of inflammation process of diseases with proinflammatory character. It was observed that chronic inflammation could be conducive in the process of carcinogenesis. It was shown that induced granulocytes could damage DNA of neighboring cells. This occurred during inflammation process in various diseases, when phagocytes release ROS not only to phagosomes but also outside the cell. Part of ROSs attack foreign objects, against which they 


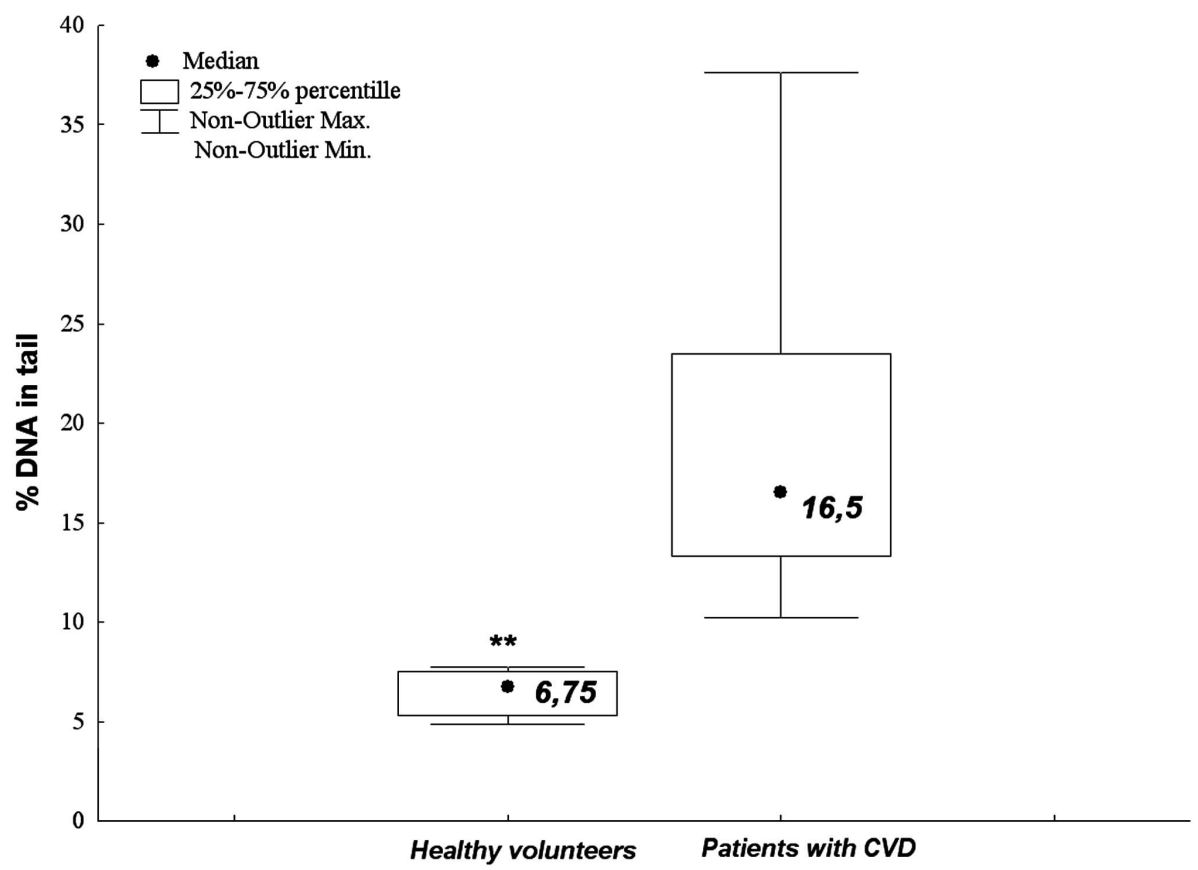

Fig. (5). The numerical value of alkali-labile DNA damages of PBLs from normal patients (the control group) being blood donors of Regional Centers of Blood Donation and Blood Therapy and PBLs from CVI patients $(* * p<0.001)$.

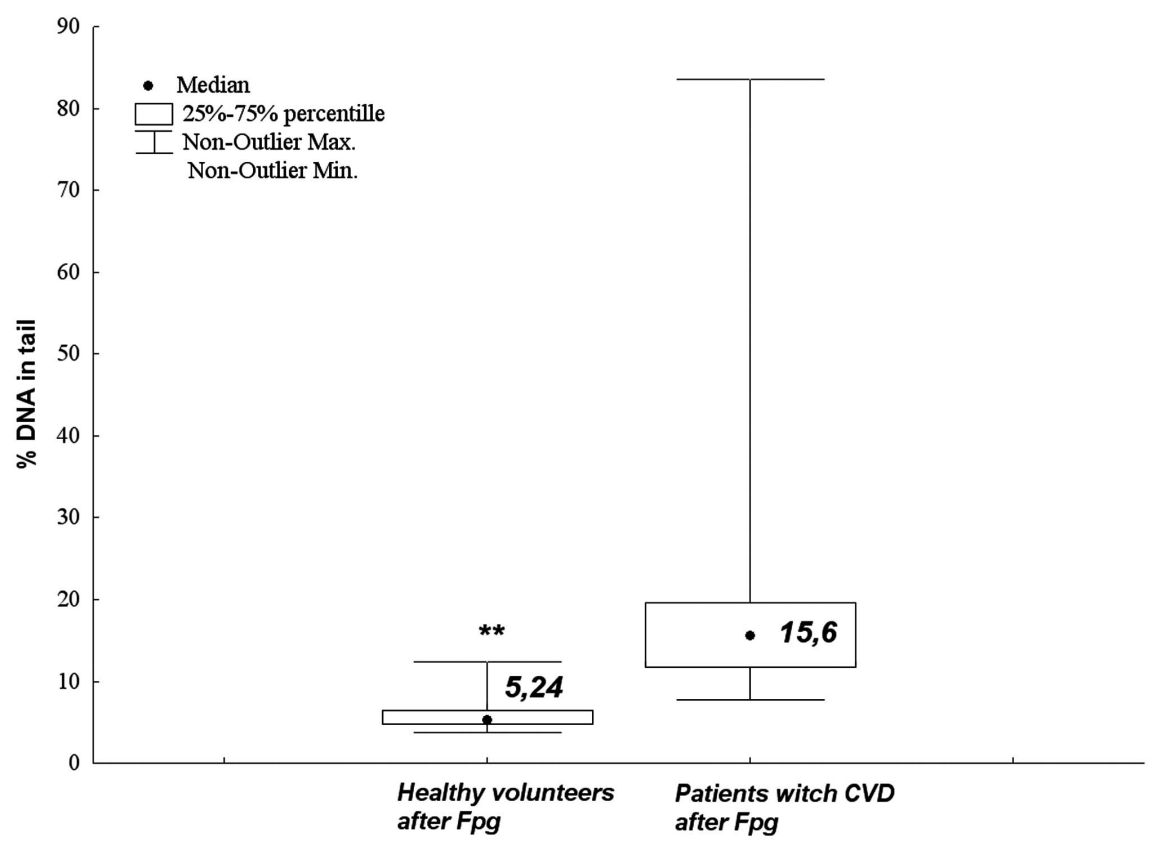

Fig. (6). The numerical value of oxidative DNA damages of PBLs from normal patients (the control group) being a blood donors of Regional Centers of Blood Donation and Blood Therapy and PBLs from CVI patients $(* * p<0.001)$.
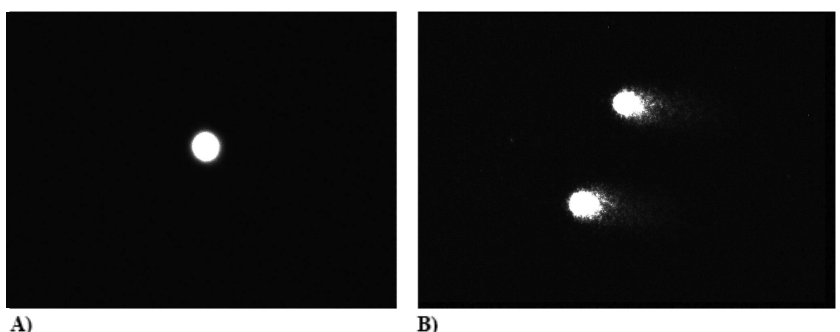

Fig. (7). PBLs from normal volunteers (A) $(n=30)$ [control] and CVI patients $[n=30]$ (B) subjected to Fpg enzyme $(0.1 / \mathrm{ml}) ; \%$ DNA (Head) - 84.4, \% DNA (Tail) - 15.6; The amount of oxidative DNA damages presented as a percentage of DNA, that left comet's head and was found in comet's tail after electrophoresis (DNA, \%). 


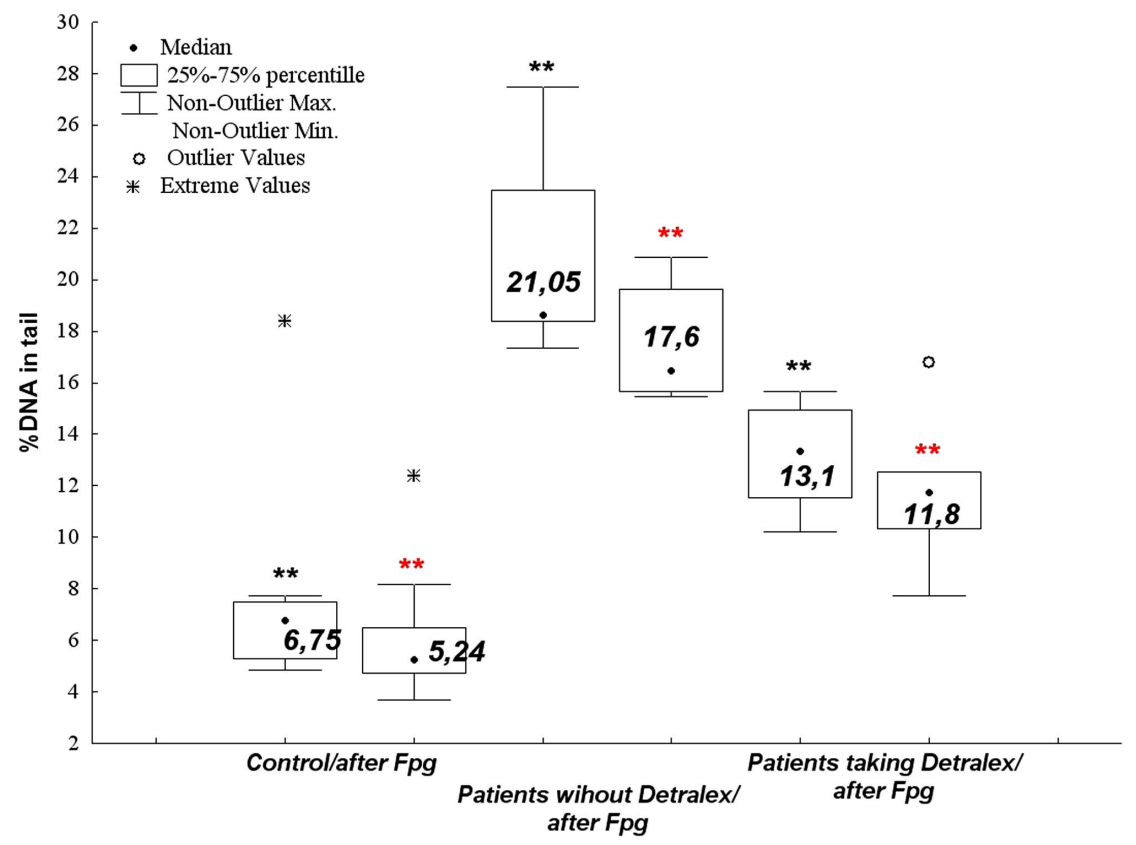

Fig. (8). The numerical value of alkali-labile/oxidative DNA damages of PBLs from normal patients (the control group) being a blood donors of Regional Centers of Blood Donation and Blood Therapy, and PBLs from CVI patients applying (one tablet twice a day) and not applying Detralex $(* * p<0.001$ vs. control)
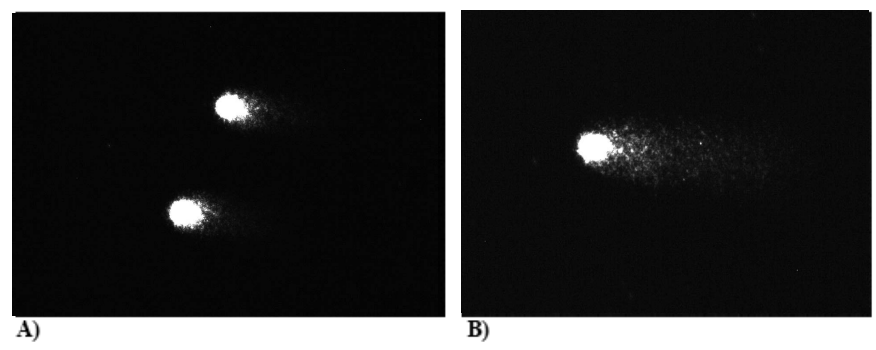

Fig. (9). Three PBLs from CVI patients $[n=30]$, who were applying Detralex (one tablet twice a day); \% DNA (Head) - 88.9, \% DNA (Tail) -11.1 and were not; \% DNA (Head) - 74.8, \%DNA(Tail) - 25.2, subjected to Fpg $(0.1 / \mathrm{ml})$. Number of oxidative DNA damages is presented as the percentage of DNA that left comet's head and was found in comet's tail after electrophoresis (DNA, \%).

are formed; however, remaining ROSs are flowing in extracellular fluids where they encounter other cells. In sites, where local inflammatory process is occurring on and many stimulated phagocytes are accumulated, concentrations of released ROSs may be high. The inflammatory reaction has a mechanism of positive feedback; exposure of plasma to action of activated phagocytes results in generation of chemotactic factors and activating new lymphocytes [11]. Generation of chemotactic factors is inhibited by SOD. It might mean that the factor responsible for SOD generation is $\mathrm{O}_{2}^{-}$ [12]. During the course of CVI, an increase in the level of hemosiderin related to Fe metabolism is observed.

In Haber-Weiss reaction, in the presence of free iron ions, with the participation of reactive biologically partially reduced oxygen forms $\left(\mathrm{O}_{2}{ }^{-}\right.$and $\left.\mathrm{H}_{2} \mathrm{O}_{2}\right)$, an $\mathrm{OH} \bullet$ free radical is formed, which can react with every biological molecule being in its direct neighborhood.

$\mathrm{Fe}^{2+}+\mathrm{H}_{2} \mathrm{O}_{2} \rightarrow \mathrm{Fe}^{3+}+\mathrm{OH}^{-}+\mathrm{OH}$

$\mathrm{Fe}^{3+}+\mathrm{O}_{2}^{-} \rightarrow \mathrm{Fe}^{2+}+\mathrm{O}_{2}$

The $\mathrm{OH} \cdot$ radical is strictly reactive, its cytotoxic effect also concerns DNA molecules, causing breaks in DNA strands (forming 8-hydroxy-2'-deoxyguanosine) [13].
In case of CVI, a relationship can be noticed between the level of oxidative DNA damages and the level of iron ions localized in the tissues. Such observations were made by Anna Jabłońska and coworkers (oxidative stress in patients with CVD. - Jabłońska P., Krzyściak W. et al., 2010 Central of European Congress of Life Sciences, Krakow, Poland 2022 Sep.), where they noticed increased level of Fe concentration in varicose veins in comparison to sufficient vessels, $30.9 \%$ and $197.16 \%$ respectively. These observations can be explained by the function, which is played by iron in CVI condition. This increase was significantly correlated with oxidative DNA damages of blood lymphocytes of CVI patients, which was observed by Wirginia Krzyściak, PhD (oxidative DNA damage in blood of CVD patients taking Detralex. - Krzyściak W. et al., 2010 Central of European Congress of Life Sciences, Krakow, Poland 20--22 Sep.). This can be explained by growing concentration of free iron catalyses changes during Haber-Weiss reaction, in which $\mathrm{OH} \cdot$ is formed. Huge amount of hydroxyl radical results in disorders of tissue functions, cells damage, destruction of proteins, lipids, carbohydrates as well as DNA. It has influence on oxidative stress, being one of the causes of CVI. Similar observations were made by Zamboni et al. 
They found increased extraction of hemosiderin with urine in patients with diagnosed vein pathology.

During free radical reaction, purine bases belonging to DNA can be oxidized, especially at position 8 of purine ring. One of the products formed in the aftermath of this reaction is 8-hydroxy-2-deoxyguanosine nucleoside.

Higher number of oxidative DNA damages is seen in acute lymphoblastic leukemia [14] where urine level of 8hydroxy-2' -deoxyguanosine (8-OH-dG) increased. The level of oxidative DNA damages increases by $50 \%$ in normal volunteers with simultaneous decrease of antioxidative pro- tection because of decrease of vitamin $\mathrm{C}$ level (from the level of $250 \mathrm{mg} /$ day to $5 \mathrm{mg}$ /day). Oxidative DNA damages increases by $50 \%$ [15]. Oxidative DNA damages accompany numerous diseases where ROSs play important role. Above mentioned phenomenon is presented in Table $\mathbf{1}$.

\section{Impact of Micronized Purified Flavonoid Fraction (MPFF) - Detralex on Level of Alkali-Labile/Oxidative DNA Damages in a Group of CVI Patients}

Hypothesis about protective effect of flavonoids, components of Detralex (diosmin, hesperidin) on oxidative DNA

Table 1. Diseases where Increased Level of Oxidative DNA Damages was Observed

\begin{tabular}{|c|c|c|}
\hline Disease & Dna Damage & Comment \\
\hline Acute Lymphoblastic leukemia & $\begin{array}{l}\text { FapyGua, 8-OH-Gua, } \\
\text { FapyAde, 8-OHAde, } \\
\text { 5-OH-Cyt, } \\
\text { 5-OH-5-MeHyd, } \\
\text { 5-OH-Hyd } a \text { (DNA }\end{array}$ & $\begin{array}{l}\text { Significant increase in DNA damage level in ALL in comparison to control } \\
(p<0.05)[20] .\end{array}$ \\
\hline Parkinson's disease & $\begin{array}{l}\text { 8-OH-dG } \\
\text { 8-OH-Guo (DNA/RNA) }\end{array}$ & Significant increase in 8-OH-dG level $(p=0.0002)$ in grey matter of brain [21]. \\
\hline Alzheimer's disease & $8-\mathrm{OH}-\mathrm{dG}$ & Higher 8-0H-dG level in cortex and cerebellum [22]. \\
\hline Amyotrophic lateral sclerosis & 8-OH-dG & Significant increase in 8-OH-dG level in comparison to control [23]. \\
\hline Primary breast cancer & 8-OH-dG (DNA) & $\begin{array}{l}\text { Increased 8-OH-dG level }(p<0.0001) \text { in carcinoma tissues in comparison to normal } \\
\text { tissues [24]. }\end{array}$ \\
\hline Cardio-vascular diseases & 8-OH-dG (DNA) & Increased 8-OH-dG level in lymphocytes $(p<0.01)$ in ischaemic heart disease [25]. \\
\hline Colorectal carcinoma & 8-OH-dG (DNA) & $\begin{array}{l}\text { Significant increase in } 8-\mathrm{OH}-\mathrm{dG} \text { level in carcinoma tissue in comparison to normal } \\
\text { mucous membrane [26]. }\end{array}$ \\
\hline Gynecological neoplasms & 8-OH-dG (urine) & $\begin{array}{l}\text { Significant increase in } 8-\mathrm{OH}-\mathrm{dG} \text { level }(p<0.05) \text { in patients with cancer in relation to } \\
\text { control [25]. }\end{array}$ \\
\hline Cervical carcinoma & 8-OH-dG (DNA) & Significant increase in 8-OH-dG level in comparison to control [27]. \\
\hline Renal cell carcinoma & 8-OH-dG (DNA) & $\begin{array}{l}\text { Significant increase in } 8 \text {-OH level }(p<0.0005) \text { in tissues changed in comparison to } \\
\text { normal tissues [28]. }\end{array}$ \\
\hline Chronic liver disease & 8-OH-dG (DNA) & Significant increase in 8-OH-dG level $(p<0.05)$ in comparison to control [29]. \\
\hline $\mathrm{HCV}$ & 8-OH-dG (DNA) & Significant increase in 8-OH-dG level $(p<0.001)$ in comparison to control [30]. \\
\hline Cystic fibrosis & 8-OH-dG (urine) & Increased level of 8-OH-dG in comparison to control [31]. \\
\hline Small cell lung carcinoma & 8-OH-dG (urine) & Increase in $8-\mathrm{OH}-\mathrm{dG}$ level in comparison to control $(p<0.05)[32]$. \\
\hline Pulmonary carcinoma & 8-OH-dG (DNA) & Increase in 8-OH-dG level in lymphocytes and carcinoma tissues [33]. \\
\hline Atopic dermatitis & 8-OH-dG (urine) & Increase in 8-OH-dG level $(p<0.0001)$ in comparison to control [34]. \\
\hline Gastric adenoma & 8-OH-dG (DNA) & $\begin{array}{l}\text { Significant increase in } 8-\mathrm{OH}-\mathrm{dG} \text { level in cancer tissues in comparison to normal } \\
\text { tissues [35]. }\end{array}$ \\
\hline Type I and II diabetes & 8-OH-dG (urine) & $\begin{array}{l}\text { Level of 8-OH-dG in patients with type I and II diabetes significantly increased in } \\
\text { comparison to control [36]. }\end{array}$ \\
\hline Down syndrome & 8-OH-dG (urine) & Increase of 8-OH-dG level in patients in comparison to control [37]. \\
\hline Rheumatoid arthritis & 8-OH-dG (urine) & Increase of $8-\mathrm{OH}-\mathrm{dG}$ level $(p<0.001)$ in comparison to control [38]. \\
\hline Chronic venous disease & 8-OH-dG (DNA) & Increase of 8-OH-dG level $(p<0.00001)$ in comparison to control [own studies] \\
\hline
\end{tabular}


damages of lymphocytes from CVI patients was confirmed. Application of Detralex in CVI patients contributes to decrease in oxidative DNA damages.

Antioxidative properties of Detralex result from its chemical structure. Due to chelating metal ions, $\mathrm{Fe}$ and $\mathrm{Cu}$, this formulation protects cells from peroxidation of lipids in cell membranes. Components of the formulation have strong antioxidative potential, higher than vitamin C [16].

Hesperidin and diosmin act as anti-inflammatory compounds, inhibiting activity of adhesion molecules and neutrophils, thus decreasing the inflammatory state [17]. Components of Detralex characterize with broad spectrum of action such as: antioxidative, anti-inflammatory, antiallergenic, anticarcinogenic, and have protective effect on vessels [18]. They are good chelators of free radicals because of reactivity of their hydroxyl groups. Due to binding metal ions, they inhibit Fenton reaction and thus limit DNA damage. Studies demonstrated that consumption of flavonoids could decrease risk of breast, colon, lung, trachea, oral cavity, and prostate cancers. Beneficial properties of hesperidin were also observed in the context of liposaccharides, cell apoptosis through activation of caspase 3 in colorectal carcinoma and nicotinic toxicity of lungs. There are studies that show the function of hesperidin in treatment of liver damages related to oxidative stress [19]. It our studies demonstrated that application of Detralex in CVI patients (one tablet two times daily) decreases the level of oxidative DNA damages. The analysis demonstrated statistically significant differences between CVI patients taking Detralex and patients not included into the therapy using this drug. Patients taking Detralex demonstrated lower level of alkali-labile/oxidative damages. The results showed significant correlation between phlebotropic drug (Detralex) and decrease in the level of alkali-labile/oxidative DNA damages.

No publications are available in databases that might report this phenomenon and enable comparison of obtained results. Thus, obtained results indicated about uniqueness of carried out studies, which demonstrate the impact of Detralex on the level of DNA damages and show new facts in the problem of CVI pathogenesis and its therapy.

\section{CONCLUSIONS}

In CVI patients, oxidative DNA damages indicate on proceeding oxidative stress. Application of Detralex confirms antioxidative action of its components (hesperidin and disomin). Correlation between decrease of the level of oxidative DNA damages and application of Detralex proves effectiveness of MPFF in prevention and treatment of CVI.

\section{ACKNOWLEDGEMENTS}

This work was supported by the Jagiellonian University Programs No. Wł/K/ZBW/000599. The Authors acknowledge Professor Marek Sanak Head of the Department of Molecular and Clinical Genetics, Jagiellonian University Medical College, Cracow, Poland for electrophoresis apparatus.

\section{STATEMENT OF AUTHORSHIP}

WK conceived of the study, and participated in its design, carried out samples, analyzed the samples, made all experiments during the study, performed the statistical analysis and data analyses and wrote the manuscript. AC participated in study design, profile image. MK participated in study design, collect clinical material. JK participated in study design, conduct and subject enrollment. All authors read and approved the final manuscript.

\begin{tabular}{|c|c|c|}
\hline \multicolumn{3}{|c|}{ ABBREVIATIONS } \\
\hline CEAP & $=$ & $\begin{array}{l}\text { Clinical state, etiology, anatomy and patho- } \\
\text { physiology }\end{array}$ \\
\hline USG & $=$ & Ultrasonography \\
\hline FDA & $=$ & Fluorescein diacetate \\
\hline EtBr & $=$ & Ethidium bromide \\
\hline CVDs & $=$ & Chronic venous diseases \\
\hline CVI & $=$ & Chronic venous insufficiency \\
\hline ROS & $=$ & Reactive oxygen species \\
\hline RNS & $=$ & Reactive nitrogen species \\
\hline $\mathrm{O}_{2}^{-\cdot}$ & $=$ & Superoxide anion \\
\hline $\mathrm{OH}^{\cdot}$ & $=$ & Hydroxyl radical \\
\hline $\mathrm{HO}_{2} \cdot$ & $=$ & Hydroperoxide radical \\
\hline $\mathrm{H}_{2} \mathrm{O}_{2}$ & $=$ & Hydroxy peroxide \\
\hline $\mathrm{O}_{2}$ & $=$ & Oxygen singlet \\
\hline 8-oxo-Gua & $=$ & 8-Oxoguanine \\
\hline HmUra & $=$ & 5-Hydroxymethyluracil \\
\hline BER & $=$ & Base-excision repair \\
\hline API & $=$ & Active pharmaceutical ingredient \\
\hline GST & $=$ & Glutathione S-transferase \\
\hline $\mathrm{K}_{2}$ EDTA & $=$ & $\begin{array}{l}\text { Ethylenediaminetetraacetic acid dipotas- } \\
\text { sium salt }\end{array}$ \\
\hline PBS & $=$ & Phosphate buffered saline \\
\hline FBS & $=$ & Fetal bovine serum \\
\hline DMSO & $=$ & Dimethyl sulfoxide \\
\hline LMPA & $=$ & Low melting point agarose \\
\hline NMPA & $=$ & Normal melting point agarose \\
\hline Fpg & $=$ & Formamidopyrimidine DNA glycosylase \\
\hline HEPES & $=$ & $\begin{array}{l}\text { [4-(2-hydroxyethyl)-1- } \\
\text { piperazineethanesulfonic acid] }\end{array}$ \\
\hline
\end{tabular}

\section{REFERENCE}

[1] Royle J, Somjen G. Varicose vein: Hippocrates to Jerry Moor. ANZ J Surg 2007; 77: 1120-7.

[2] Sheu S, Nauduri D, Anders M. Targeting antioxidants to mitochondria: A new therapeutic direction. Biochemica et Biophysica Acta 2006; 256-65.

[3] Cadet J, Delatour T, Douki T, et al. Hydroxyl radicals and DNA base damage Mutation Research/Fundamental and Molecular Mechanisms of Mutagenesis. 1999; 424(1-8): 9-21.

[4] Puzanowska H, Kuźmicka L, Tarasiewicz M. Wpływ reaktywnych form azotu i tlenu na organizm człowieka. Pol Merk Lek 2009; 27 : $162,496$.

[5] Loft S, Danielsen P, Mikkelsen L. Biomarkers of oxidative damage to DNA and repair. Biochem Soc Trans 2008; 36: 1071-6. 
[6] Jantet G. Chronic venous insufficiency: worldwide results of the RELIEF study. Reflux assEssment and quaLity of lIfe improvement with micronized Flavonoids. Angiology 2002; 53: 245-56.

[7] Collins AR, Dušinská M. Oxidation of Cellular DNA Measured with the Comet Assay Methods in Molecular Biology, vol. 186: Oxidative Stress Biomarkers and Antioxidant Protocols Edited by: D. Armstrong (C) Humana Press Inc., Totowa, NJ 2002; 147-159.

[8] Strauss GH. Non-random cell killing in cryopreservation: implications for performance of the battery of leukocyte tests (BLT), I. Toxic and immunotoxic effects. Mutat Res 1991; 252: p. 1-15.

[9] Chetsanga C J, Lindahl T. Release of 7-methylguanine residues whose imidazole rings have been opened from damaged DNA by a DNA glycosylase from Escherichia coli. Nucleic Acids Res 1979; 10; 6: 3673-84.

[10] Kapiszewska M, Cierniak A, Elas M, Lankoff A. Lifespan of etoposide-treated human neutrophils is affected by antioxidant ability of quercetin. Toxicol Vitro 2007; 21: 1020-30.

[11] Madamanchi N, Vendrov A, Runge M. Oxidative stress and vascular disease. Arterioscler Thromb Vasc Biol 2005; 25: 29-38.

[12] Cooke M, Evans M, Dizdaroglu M. Oxidative DNA damage: mechanism, mutation and disease. FASEB J 2003; 17:1195-214.

[13] Oliński R, Jurgowiak M. Iron metabolizm, oxidative DNA damage and atherosclerosis. Acta Angiologia 2002; 8: 2: 37-44.

[14] Honda M, Yamada Y, Tomonaga M, Ichinose H, Kamihira S. Correlation of urinary 8-hydroxy-2-deoxyguanosine (8-OHdG), a biomarker of oxidative DNA damage, and clinical features of hematological disorders: a pilot study. Leuk Res 2000; 24: 461-8.

[15] Fraga CG, Motchnik PA, Shigenaga MK, Helbock HJ, Jacob RA, Ames BN. Ascorbic acid protects against endogenous oxidative DNA damage in human sperm. Proc Natl Acad Sci USA 1991; 88: 11003-6.

[16] Noroozi M, Angerson W, Lean M. Effects of flavonoids and vitamin $\mathrm{C}$ on oxidative DNA damage to human limphfocytes. Am J Clin Nutr 1998; 67: 1210-8.

[17] Chudek J. Skuteczność i tolerancja diosminy w leczeniu chorych z przewlekłą niewydolnością żylną w codziennej praktyce klinicznej. Probl Med Rodz 2008; 4: 45-1.

[18] Kalpana K, Devipriya N, Srinivasan M. Investigation of the radioprotective efficacy of hesperidin against gamma-radiation induced cellular damage in cultured human peripheral blood lymphocytes. Mut Res 2009; 676: 54-61.

[19] Horcajada M, Habauzit V, Trzeciakiewicz A. Hesperidin inhibits ovariectomized-induced osteopenia and shows differentia effects on bone mass and strength in young and adult intact rats. J Appl Physiol 2008; 104: 648-54.

[20] Stenturker S, Karahalil B, Inal M. OxidativeDNA base damage and antioxidant enzyme levels in childhood acute lymphoblastic leukemia. FEBS Lett 1997; 416: 286-90.

[21] Alam Z, Jenner A, Daniel S. Oxidative DNA damage in the parkinsonian brain: an apparent selective increase in 8-hydroxyguanine levels in substantia nigra. J Neurochem 1997; 69: 1196-203.

[22] Markesbery WR, Lovell MA. DNA oxidation in Alzheimer's disease. Antioxid Redox Signal 2006; 8: 2039-45.
[23] Bogdanov M, Brown R, Matson W. Increased oxidative damage to DNA in ALS patients. Free Radic Biol Med 2000; 29: 652-8.

[24] Matsui A, Ikeda T, Enomoto K. Increased formation of oxidative DNA damage, 8-hydroxy-2-deoxyguanosine, in human breast cancer tissue and its relationship to GSTP1 and COMT genotypes. Cancer Lett 2000; 151: 87-95.

[25] Collins A, Gedik C, Olmedilla B. Oxidative DNA damage measured in human lymphocytes: large differences between sexes and between countries, and correlations with heart disease mortality rates. FASEB J 1998; 12: 1397-400.

[26] Oliva M, Ripoll F, Muniz P. Genetic alterations and oxidative metabolism in sporadic colorectal tumors from a Spanish community. Mol Carcinog 1997; 18: 232-43.

[27] Romano G, Sgambato A, Mancini R. 8-Hydroxy-2-deoxyguanosine in cervical cells: correlation with grade of dysplasia and human papillomavirus infection. Carcinogenesis 2000; 21: 1143-7.

[28] Okamoto K, Toyokuni S, Uchida K. Formation of 8-hydroxy-2 deoxyguanosine and 4-hydroxy-2-nonenal-modified proteins in human renalcell carcinoma. Int J Cancer 1994; 58: 825-9.

[29] Shimoda R, Nagashima M, Sakamoto M. Increased formation of oxidative DNA damage, 8 hydroxydeoxyguanosine, in human livers with chronic hepatitis. Cancer Res 1994; 54: 3171-2.

[30] Kato J, Kobune M, Nakamura T. Normalization of elevated hepatic 8-hydroxy- 2_-deoxyguanosine levels in chronic hepatitis $\mathrm{C}$ patients by phlebotomy and low iron diet. Cancer Res $2001 ; 61$ : 8697-702.

[31] Jaruga P, Zastawny T, Skokowski J. Oxidative DNA base damage and antioxidant enzyme activities in human lung cancer. FEBS Lett 1994; 341: 59-64.

[32] Hardie L, Briggs J, Davidson L. The effect of hOGG1 and glutathione peroxidase I genotypes and $3 p$ chromosomal loss on 8 hydroxydeoxyguanosine levels in lung cancer. Carcinogenesis 2000; 21: 167-72.

[33] Vulimiri S, Wu X, Baer-Dubowska W. Analysis of aromatic DNA adducts and 7,8-dihydro-8-oxo-2-deoxyguanosine in lymphocyte DNA from a case-control study of lung cancer involving minority populations. Mol Carcinog 2000; 27: 34-46.

[34] Matsui M, Nishigori C, Toyokuni S. The role of oxidative DNA damage in human arsenic carcinogenesis: detection of 8-hydroxy2-deoxyguanosine in arsenic-related Bowen's disease. J Invest Dermatol 1999; 113: 26-31.

[35] Lee B, Jang J, Kim H. Benzo[a]pyrene diol-epoxide-I-DNA and oxidative DNA adducts associated with gastric adenocarcinoma. Cancer Lett 1998; 125: 61-8.

[36] Krapfenbauer K, Birnbacher R, Vierhapper H. Glycoxidation, and protein and DNA oxidation in patients with diabetes mellitus. Clin Sci (London) 1998; 95: 331-7.

[37] Seidl R, Greber S, Schuller E. Evidence against increased oxidative DNA damage in Down syndrome. Neurosci Lett 1997; 235:137-40.

[38] Lunec J, Herbert K, Blount S. 8-Hydroxydeoxyguanosine. A marker of oxidative DNA damage in systemic lupus erythematosus. FEBS Lett 1994; 348: 131-8.

Received: April 18, 2011

Revised: April 29, 2011

Accepted: April 30, 2011

(C) Wirginia et al.; Licensee Bentham Open.

This is an open access article licensed under the terms of the Creative Commons Attribution Non-Commercial License (http:/creativecommons.org/licenses/ by-nc/3.0/) which permits unrestricted, non-commercial use, distribution and reproduction in any medium, provided the work is properly cited. 